\title{
Multiplikasi Tunas Tebu (Saccharumo officinarum L Var. Bululawang) dengan Perlakuan Konsentrasi BAP dan Kinetin Secara In Vitro
}

\section{Multiplication of Shoot Sugarcane (Saccharumo officinarum L Var. Bululawang) on Concentration of BAP and Kinetin In Vitro}

\author{
Chory Praseptiana $^{1 *}$, Sri Darmanti $^{2}$, Erma Prihastanti $^{2}$ \\ ${ }^{1)}$ Program Studi Biologi, Departemen Biologi, Fakultas Sains dan Matematika, Universitas Diponegoro \\ ${ }^{2)}$ Departemen Biologi, Fakultas Sains dan Matematika, Universitas Diponegoro \\ Jl. Prof. Soedarto, SH, Tembalang, Semarang \\ *Email: chorynopraseptiana@gmail.com
}

Diterima 24 Maret 2017 / Disetujui 24 Agustus 2017

\begin{abstract}
ABSTRAK
Tebu (Saccharum officinarum L var. Bululawang) merupakan tebu varietas unggul yang memiliki daya adaptasi dan stabilitas baik pada berbagai jenis tanah, tetapi bibit yang dihasilkan masih sedikit karena dominansi apikal yang tinggi sehingga untuk memperbanyak bibitnya diperlukan teknik khusus. Multiplikasi tunas dengan teknik kultur in vitro merupakan teknik alternatif untuk memperbanyak bibit tebu yang berkualitas, dalam jumlah yang besar dan waktu yang singkat. Sitokinin merupakan ZPT yang berperan dalam multiplikasi tunas. Pemberian konsentrasi sitokinin berupa BAP dan kinetin diharapkan mampu menjelaskan multiplikasi tunas. Penelitian ini bertujuan untuk mengkaji pengaruh konsentrasi BAP dan kinetin terhadap waktu munculnya tunas dan pertumbuhan tunas tebu Bululawang secara in vitro. Eksplan yang digunakan berupa mata tunas tebu Bululawang umur 6-8 bulan yang terdapat pada bagian nodus. Penelitian ini menggunakan Rancangan Acak Lengkap (RAL) dengan 12 perlakuan, masing-masing 3 ulangan. Eksplan dikulturkan selama 8 minggu pada media MS dengan konsentrasi BAP $(0,0,5,1$, dan $2 \mathrm{mg} / \mathrm{l})$ dan kinetin $(0$, $0,5$, dan $1 \mathrm{mg} / \mathrm{l})$. Parameter yang diamati, yaitu: waktu munculnya tunas (HST), panjang tunas (cm), jumlah tunas, jumlah daun (helai), dan warna daun. Data yang diperoleh kemudian dianalisis menggunakan uji ANOVA pada taraf signifikan $95 \%$. Hasil analisis data menunjukkan tidak adanya pengaruh pemberian BAP dan kinetin sampai konsentrasi $2 \mathrm{mg} / \mathrm{l}$ dan $1 \mathrm{mg} / \mathrm{l}$ terhadap parameter multiplikasi tunas tebu var. Bululawang.
\end{abstract}

Kata kunci : tunas, Bululawang, BAP, kinetin

\section{ABSTRACT}

Sugarcane (Saccharum officinarum L var. Bululawang) is superior sugarcane variety that have survive and good stability in various of type soil but seed was low produced cause high apical dominance, so we need special technice for scale up it's seed. In vitro plant culture is alternative technice for produced quality sugarcane seed, high number of seed with shoot multiplication. Cytokinin is PGR that role shoot multiplication. The consentration cytokinin as BAP and kinetin that able expected to influence shoot multiplication. This research aims to review the influence of consentration BAP and kinetin for shoot initiation and growth of Bululawang sugarcane. Explants were used Bululawang shoot's sugarcane that age 68 months, located on the node. This research was used RAL with 12 treatment, and each 3 replicated. Explants cultured during 8 weeks in MS media with consentration BAP $(0,0,5,1$, dan $2 \mathrm{mg} / \mathrm{l})$ and kinetin $(0,0,5$, dan 1 $\mathrm{mg} / \mathrm{l})$. Parameters were observed namely: appear shoot time (HST), length of shoot (cm), number of shoot, number of leaf, and colour of leaf. The date were analyzed using ANOVA at the confidence level $95 \%$. The result showed that no influence of BAP and kinetin consentration to $2 \mathrm{mg} / \mathrm{l}$ and $1 \mathrm{mg} / \mathrm{l}$ for shoot multiplication parameter of Sugarcane var. Bululawang.

Keywords:shoot, Bululawang, BAP, kinetin 


\section{PENDAHULUAN}

Tebu (Saccharum officinarum L) merupakan bahan baku utama dalam pembuatan gula, sehingga mempunyai nilai ekonomis yang tinggi (Sukmadajaja, 2011). Menurut Ramadhan dkk. (2014) tebu varietas Bululawang sangat potensial karena memiliki daya adaptasi dan stabilitas yang baik pada berbagai jenis tanah serta memiliki rendemen yang tinggi yaitu sekitar 7,51\%. Selama ini perbanyakan tebu Bululawang dilakukan secara vegetatif melalui stek, akan tetapi menurut Murwandono (2013) pembentukan tunas dengan stek cukup lama yaitu 2 sampai 4 bulan dan dari satu mata tunas hanya menghasilkan satu tunas, sehingga bibit yang dihasilkan sedikit (Priyono dkk., 2000), dan bibit mudah terinfeksi patogen penyebab penyakit (Malabadi et al., 2011).

Teknik kultur in vitro merupakan cara alternatif pengadaan bibit tebu yang berkualitas (FAO, 2008). Penyediaan bibit melalui kultur in vitro dapat dihasilkan bibit tebu dalam jumlah besar dengan waktu singkat serta bibit yang dihasilkan sehat dan seragam (George et al., 2008). Pengadaan bibit tebu melalui kultur in vitro dapat dilakukan dengan multiplikasi tunas, namun kendalanya laju pertumbuhan pada tebu Bululawang lambat karena dominansi apikal tinggi (P3GI, 2008) sehingga diberikan sitokinin pada media kultur in vitro (MS).

Menurut Niaz dan Quraishi (2002), sitokinin berperan dalam mengendalikan dominansi apikal dan menghilangkan dormansi tunas lateral, sehingga untuk memicu multiplikasi tunas diperlukan zat pengatur tumbuh sitokinin. Kinetin (6-furfuryl aminopurin) dan BAP (Benzyl Amino Purin) merupakan sitokinin sintetis yang berperan dalam menginduksi tunas (Schmulling, 2004). Kinetin berperan dalam ekspresi gen, mengaktivasi siklus sel, merangsang aliran $\mathrm{Ca}^{+2}$, dan mencegah penuaan pada tanaman (Gaudino dan Pikkard, 1997), sedangkan BAP mempunyai aktivitas lebih stabil dan tahan terhadap oksidasi dibandingkan sitokinin lainnya (Nurjanah, 2009). Menurut (George et al., 2008), konsentrasi BAP dan kinetin yang tepat dapat meningkatkan multiplikasi tunas.
Menurut Vujovic et al. (2012) parameter yang diamati untuk mengetahui multiplikasi tunas, yaitu induksi tunas, panjang tunas, jumlah tunas, jumlah daun, dan warna tunas. Berdasarkan hasil penelitian Sukmadjaja (2011) pemberian BAP 2 $\mathrm{mg} / \mathrm{l}$ dan kinetin $1 \mathrm{mg} / \mathrm{l}$ mampu menginisiasi munculnya tunas tebu Bululawang pada usia 10 HST, sedangkan pada penelitian Ali et al. (2008) pemberian BAP $0,5 \mathrm{mg} / \mathrm{l}$ dan kinetin $0,25 \mathrm{mg} / \mathrm{l}$ mampu menginisiasi munculnya tunas tebu BL-4 tercepat pada usia 10 HST dengan rata-rata jumlah tunas 1,94. Percobaan yang dilakukan Khan et al. (2009) pada multiplikasi tunas tebu varietas CPF237 pada pemberian BAP $1 \mathrm{mg} / \mathrm{l}$ dan kinetin 0,1 $\mathrm{mg} / \mathrm{l}$ dihasilkan tunas sebanyak 11 anakan selama 30 hari.

Penelitian kultur in vitro ini menggunakan eksplan mata tunas tebu (Saccharum officinarum var. Bululawang) usia 6 bulan pada medium MS dengan pemberian konsentrasi BAP (Benzyl Amino Purine) dan kinetin (6-furfuryl aminopurine). Penelitian bertujuan untuk mengetahui konsentrasi BAP dan kinetin yang optimal untuk multiplikasi tunas tebu var. Bululawang secara in vitro. Mata tunas merupakan organ yang tersusun oleh jaringan muda yang sel-selnya masih aktif membelah (meristematik). Penggunaan mata tunas pada kultur in vitro diduga lebih efektif karena sudah terbentuk calon tunas yang diharapkan dapat membentuk tunas secara langsung sehingga dapat memotong satu tahapan kultur in vitro.

\section{METODE PENELITIAN}

\section{Waktu dan Tempat}

Penelitian dilaksanakan pada bulan April sampai dengan Juni 2016 di Pusat Penelitian dan Pengembangan Perum Perhutani Cepu.

\section{Alat dan Bahan}

Alat-alat yang digunakan dalam penelitian ini, yaitu botol kultur, gelas ukur, pipet tetes, gelas bekker, timbangan analitik, $\mathrm{pH}$ meter, spatula, spidol, stopwatch, autoclave, Laminar Air Flow Cabinet (LAF), magnetic stirrer, water bath, hot plate, alas papan, scalpel, pinset, bunsen, pisau, 
inkubator, refrigerator, kamera, sprayer, alumunium foil, sikat, dan cutter.

Bahan-bahan yang digunakan, yaitu mata tunas tebu var. Bululawang umur 6 bulan yang diperoleh dari kebun tebu di Kecamatan Ungaran Timur, aquades steril, $\mathrm{NaOH} 0,1 \mathrm{~N}, \mathrm{HCl} 0,1 \mathrm{~N}$, medium MS lengkap dengan penambahan BAP dan kinetin pada tabel L.1, dan $0,02 \%$ (v/v) $\mathrm{HgCl}_{2}$, alkohol 70\%, spirtus, sabun cair, dan deterjen.

\section{Cara Kerja Penelitian}

1. Sterilisasi Alat dan Botol: semua alat dicuci, dikeringkan pada rak pengering, dan disterilisasi pada autoklaf suhu $121^{\circ} \mathrm{C}$ tekanan 1,5 atm selama 20 menit. Sterilisasi dilanjutkan dengan menggunakan oven pada suhu $60^{\circ} \mathrm{C}$ selama 30 menit. Alat-alat dari logam seperti, scalpel, dan pinset dimasukkan ke dalam alkohol $96 \%$ dan dipanaskan pada api bunsen.

2. Pembuatan Larutan Stok ZPT: BAP dan kinetin masing-masing ditimbang sebanyak 0,01 gram, kemudian masing-masing dilarutkan dalam 100 $\mathrm{ml}$ aquades steril dan dihomogenkan dengan magnetic stirrer. Larutan stok ZPT disimpan dalam refrigerator.

3. Pembuatan Media MS: unsur mikro, unsur makro, dan senyawa organik pada komposisi media MS yang telah dibuat menjadi larutan stok diambil sesuai takaran per liter media, kemudian ditambahkan sukrosa $30 \mathrm{~g} / \mathrm{l}$ dan agar $8,5 \mathrm{~g} / \mathrm{l}$ serta ditambahkan aquades sampai volume larutan menjadi $1000 \mathrm{ml}$. Larutan dihomogenkan dengan menggunakan magnetic stirrer sampai homogen.

4. Perlakuan ZPT pada media kultur: media MS dituangkan pada botol, kemudian ditambahkan larutan stok BAP dan kinetin (sesuai perlakuan) keadaan diaduk menggunakan magnetic stirrer sampai homogen. $\mathrm{pH}$ campuran diatur hingga 5,8 dengan menambahkan $0,1 \mathrm{~N} \mathrm{NaOH}$ atau $0,1 \mathrm{~N} \mathrm{HCl}$. Larutan disterilisasi pada autoklaf dengan suhu $121^{\circ} \mathrm{C}$ tekanan 1,5 atm selama 20 menit. Selanjutnya media disimpan pada ruang penyimpanan media.

5. Persiapan Eksplan: mata tunas tebu varietas Bululawang usia 6 sampai 8 bulan yang digunakan yaitu bagian paling ujung meristem, dengan ukuran 1 sampai $2 \mathrm{~cm}$ dan dicuci dengan air keran selama 30 menit. Eksplan disiapkan dan diletakkan di sekitar LAF.

6. Sterilisasi Eksplan dan Penanaman:

- Mata tunas direndam dalam larutan $0,02 \%$ (v/v) $\mathrm{HgCl}_{2}$ sambil digojog selama 3 menit dilakukan 2 kali.

- Mata tunas dibilas dengan aquades steril dilakukan 2 kali.

- Mata tunas direndam dalam alkohol $70 \%$ sambil digojog selama 5 menit.

- Mata tunas dibilas dengan aquades steril dilakukan 2 kali.

7. Penanaman Eksplan:

- Eksplan dipotong dengan ukuran $1 \mathrm{~cm}$ dan disayat pada bagian nodusnya menggunakan scalpel.

- Eksplan ditanam dalam media MS dengan tiap perlakuan dilakukan tiga ulangan.

- Kultur diberi label sesuai tanggal penanaman, dan diinkubasi pada suhu $25^{\circ} \mathrm{C} \pm 2^{0} \mathrm{C}$ dengan 16 jam periode terang dan 8 jam periode gelap, intensitas cahaya 2500 sampai 3000 lux dan kelembapan $75 \%$ samapi $80 \%$ selama 8 minggu.

- Pengamatan visual dilakukan setiap hari selama 8 minggu, dan kultur yang terkontaminasi dikeluarkan dari ruang kultur.

Penelitian ini menggunakan Rancangan Acak Lengkap (RAL) dengan 12 perlakuan ZPT, yaitu:

P0 : (Kontrol) tanpa zat pengatur tumbuh

P1 : $0,5 \mathrm{mg} / \mathrm{l}$ kinetin

$\mathrm{P} 2: 1 \mathrm{mg} / \mathrm{l} \mathrm{kinetin}$

P3 : 0,5 mg/l BAP

$\mathrm{P} 4: 1 \mathrm{mg} / \mathrm{l} \mathrm{BAP}$

$\mathrm{P} 5: 2 \mathrm{mg} / \mathrm{l} \mathrm{BAP}$

P6 : $0,5 \mathrm{mg} / \mathrm{l} \mathrm{BAP}+0,5 \mathrm{mg} / 1$ kinetin

$\mathrm{P} 7: 0,5 \mathrm{mg} / \mathrm{l} \mathrm{BAP}+1 \mathrm{mg} / \mathrm{l} \mathrm{kinetin}$

P8 : $1 \mathrm{mg} / \mathrm{l} \mathrm{BAP}+0,5 \mathrm{mg} / \mathrm{l}$ kinetin

$\mathrm{P} 9: 2 \mathrm{mg} / \mathrm{l} \mathrm{BAP}+0,5 \mathrm{mg} / \mathrm{l} \mathrm{kinetin}$

P10: $2 \mathrm{mg} / \mathrm{l} \mathrm{BAP}+0,5 \mathrm{mg} / \mathrm{l}$ kinetin

P11: $2 \mathrm{mg} / \mathrm{l} \mathrm{BAP}+1 \mathrm{mg} / \mathrm{l}$ kinetin 
Masing-masing perlakuan dengan 3 ulangan, setiap botol kultur masing-masing berisi satu eksplan.

\section{Parameter Penelitian}

1. Waktu munculnya tunas (HST) pada eksplan: diamati setelah inokulasi sampai muncul tonjolan kehijauan pada eksplan dengan ukuran lebih $2 \mathrm{~mm}$.

2. Jumlah tunas: dihitung tunas yang tumbuh setiap eksplan yang hidup setelah inkubasi sampai akhir pengamatan (3 MST).

3. Tinggi tunas $(\mathrm{cm})$ : diukur dari pangkal nodus sampai ujung tunas setelah eksplan diinkubasi sampai akhir pengamatan (3 MST).
4. Jumlah daun (helai): dihitung dari munculnya tunas sampai sampai akhir pengamatan (3 MST).

5. Morfologi tunas: diamati secara visual setiap hari sampai akhir pengamatan (3 MST)

\section{Analisis Data}

Data jumlah tunas, panjang tunas, jumlah daun dan waktu pembentukan tunas dianalisis dengan uji ANOVA dengan taraf signifikansi 95\%, dilanjutkan uji lanjutan Duncan's Multiple Range Test (DMRT).

\section{HASIL DAN PEMBAHASAN}

Tabel 1. Rata-rata waktu munculnya tunas (HST), panjang tunas (cm), jumlah tunas, dan jumlah daun (helai) pada tebu (Saccharum officinarum var. Bululawang) setelah perlakuan konsentrasi BAP dan kinetin yang berbeda

\begin{tabular}{ccccc}
\hline & \multicolumn{4}{c}{ Rata-rata } \\
\cline { 2 - 5 } Perlakuan & $\begin{array}{c}\text { Waktu } \\
\text { munculnya } \\
\text { tunas } \\
\text { (HST) }\end{array}$ & $\begin{array}{c}\text { Panjang } \\
\text { tunas } \\
(\mathrm{cm})\end{array}$ & $\begin{array}{c}\text { Jumlah } \\
\text { tunas } \\
\text { (tunas) }\end{array}$ & $\begin{array}{c}\text { Jumlah } \\
\text { daun } \\
\text { (helai) }\end{array}$ \\
\hline P0 & 2,33 & 0,97 & 1 & 1,39 \\
P1 & 2,78 & 2,40 & 1 & 1,25 \\
P2 & 2,78 & 2,46 & 2 & 2,41 \\
P3 & 2,56 & 4,67 & 1,33 & 2,34 \\
P4 & 2,56 & 1,77 & 2,67 & 2,86 \\
P5 & 2,81 & 3,23 & 1,67 & 2,30 \\
P6 & 2,56 & 4,46 & 4,46 & 3,74 \\
P7 & 3,01 & 0,83 & 3,23 & 0,71 \\
P8 & 2,24 & 2,31 & 3,33 & 2,54 \\
P9 & 1,48 & 3,6 & 1 & 2,42 \\
P10 & 1,95 & 3,38 & 1,67 & 3,51 \\
P11 & 2,16 & 4,35 & 1,33 & 2,58 \\
\hline
\end{tabular}

Keterangan: P0: Tanpa zat pengatur tumbuh; P1: 0,5 mg/l kinetin; P2: $1 \mathrm{mg} / \mathrm{l}$ kinetin; P3: 0,5 mg/l BAP; P4: $1 \mathrm{mg} / \mathrm{l} \mathrm{BAP}$; P5: $2 \mathrm{mg} / \mathrm{l} \mathrm{BAP}$; P6: 0,5 mg/l BAP + 0,5 mg/l kinetin; P7: 0,5 mg/l BAP + $1 \mathrm{mg} / \mathrm{l} \mathrm{kinetin;} \mathrm{P8:} 1 \mathrm{mg} / \mathrm{l} \mathrm{BAP} \mathrm{+}$ 0,5 mg/l kinetin; P9: $1 \mathrm{mg} / \mathrm{l} \mathrm{BAP} \mathrm{+} 1 \mathrm{mg} / \mathrm{l}$ kinetin; P10: $2 \mathrm{mg} / \mathrm{l} \mathrm{BAP} \mathrm{+} \mathrm{0,5} \mathrm{mg/l} \mathrm{kinetin;} \mathrm{P11:} 2$ mg/l BAP + 1 $\mathrm{mg} / \mathrm{l} \mathrm{kinetin}$

Hasil uji ANOVA (Analysis of Variance) pada taraf signifikansi $95 \%$ menunjukkan bahwa perlakuan BAP dan kinetin tidak berpengaruh terhadap rata-rata waktu munculnya tunas tebu var. Bululawang (Tabel 1).
Perlakuan tanpa zat pengatur tumbuh tetap menginduksi munculnya tunas, akan tetapi pada perlakuan P9 dengan konsentrasi BAP $1 \mathrm{mg} / \mathrm{l}$ dan kinetin $1 \mathrm{mg} / \mathrm{l}$ cenderung memberikan hasil tercepat waktu munculnya tunas dibandingkan P0 
(kontrol) (Tabel 1). Hal itu kemungkinan karena pemberian sitokinin pada konsentrasi tersebut mampu meningkatkan konsentrasi hormon endogen dalam eksplan, yang kemudian merangsang pembelahan sel dan diferensiasi sel pada eksplan.

Menurut Ali et al. (2008), induksi tunas tebu terjadi karena proses pembelahan sel dan diferensiasi sel meristem yang dipengaruhi oleh keseimbangan dan interaksi hormon eksogen dengan hormon endogen. Hormon sitokinin berperan penting dalam pembelahan sel dan diferensiasi sel. Diferensiasi sel terjadi jika sel sudah mencapai volume maksimal, kemudian sel akan terspesialisasi dalam bentuk dan fungsi tertentu.

Menurut Harjadi (2009), pemberian BAP memacu sintesis protein sehingga mendorong terjadinya pembelahan sel yang menginduksi terbentuknya tunas. Menurut Hayati dkk (2010) sitokinin secara langsung berperan pada tahap interfase saat terjadinya proses transkripsi DNA dan translasi RNA untuk mensintesis protein. Protein yang terbentuk akan menyusun enzimenzim yang berperan dalam pembelahan sel, yaitu enzim polimerase yang berperan dalam memperpanjang rantai DNA serta memperbaiki kesalahan penyusunan basa nitrogen, enzim ligase yang berperan dalam menggabungkan fragmen DNA, dan enzim kinase yang berperan mengontrol siklus sel. Adanya enzim-enzim tersebut proses pembelahan sel lebih efektif.

\section{Panjang tunas, jumlah tunas dan jumlah daun tebu (Saccharum officinarum $\mathrm{L}$ var. Bululawang)}

Hasil uji ANOVA pada taraf signifikan 95\% menunjukkan bahwa perlakuan BAP dan kinetin tidak berpengaruh terhadap panjang tunas, jumlah tunas, dan jumlah daun tebu var. Bululawang (Tabel 1). Tabel 1 menunjukkan tunas dengan perlakuan tanpa zat pengatur tumbuh tetap mengalami pertumbuhan. Hal tersebut karena eksplan mengandung hormon endogen serta pada medium MS tersedia nutrisi untuk pertumbuhan eksplan. P3 cenderung memberikan hasil tertinggi panjang tunas tebu var. Bululawang dibandingkan perlakuan kontrol. Perlakuan P6 yaitu: $0,5 \mathrm{mg} / \mathrm{l}$ BAP dan $0,5 \mathrm{mg} / \mathrm{l}$ kinetin cenderung memberikan hasil jumlah tunas dan jumlah daun terbanyak dibandingkan perlakuan kontrol, meskipun demikian pada perlakuan P0 (kontrol) tanpa pemberian BAP dan kinetin tetap terbentuk tunas dan daun. Menurut Lack (2001) eksplan memiliki hormon endogen yang berperan dalam pembelahan sel dan diferensiasi sel serta mengatur pertumbuhan dan perkembangan tumbuhan, akan tetapi hormon tersebut dimilki tumbuhan dengan konsentrasi rendah.

Menurut Pierick (1982) sitokinin berperan dalam merangsang sintesis protein dan meningkatkan aktivitas sel-sel penyusun jaringan meristem. Sel-sel akan aktif membelah dan mengalami diferensiasi membentuk struktur dengan fungsi spesifik, setelah sel matang akan kehilangan kemampuan untuk membelah. Sel yang tumbuh dan berdiferensiasi akan berkembang membentuk jaringan penyusun tunas, dan daun tumbuhan. Pertumbuhan sel dan diferensiasi sel akan mempengaruhi morfogenesis.

\section{Morfologi pada tunas tebu (Saccharum officinarum $L$ var. Bululawang)}

Data kualitatif berupa morfologi tunas tebu var. Bululawang diperlukan untuk mendukung data kuantitatif pada tabel 1. Gambar 1 dan Tabel 2 menunjukkan bahwa perlakuan tanpa zat pengatur tumbuh (Gambar 1.A) pada mata tunas menghasilkan tunas berwarna hijau tua dan belum memiliki daun. Hal tersebut karena unsur hara mengandung ion $\mathrm{Mg}^{2+}$ sebagai penyusun klorofil, meskipun tanpa pemberian ZPT tetapi tetap dihasilkan klorofil. Menurut Ai dan Yunia (2010), warna hijau pada daun dan tunas disebabkan karena kandungan klorofil di dalam kloroplas yang terdapat pada jaringan parenkim palisade dan parenkim spon daun. Menurut Kocot et al. (2011), pemberian sitokinin berfungsi dalam pembentukan klorofil khususnya mendukung transport ion $\mathrm{Mg}^{2+}$ ke dalam sel-sel mesofil daun, tetapi pemberian sitokinin dengan konsentrasi tinggi akan menurunkan akumulasi $\mathrm{Mg}^{2+}$ sehingga sintesis klorofil terganggu. 


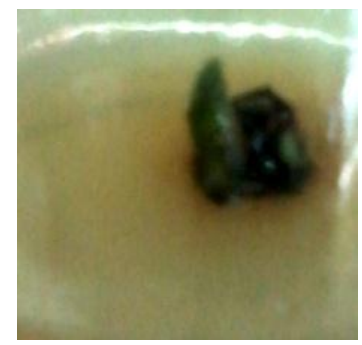

P0

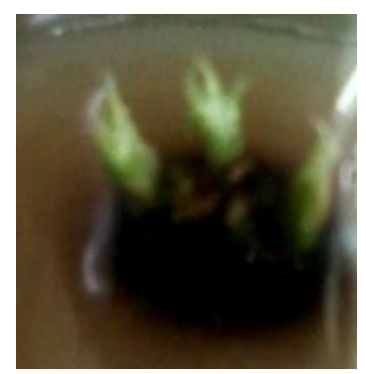

P4

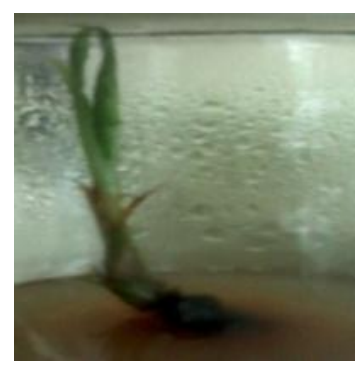

P8

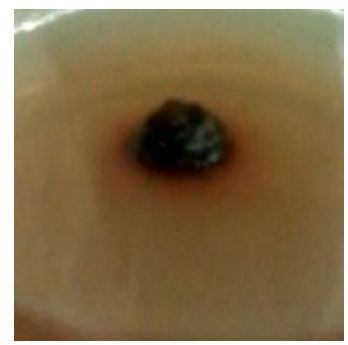

P1

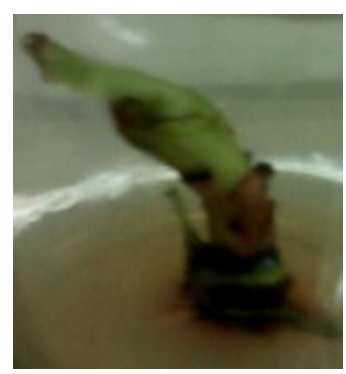

P5

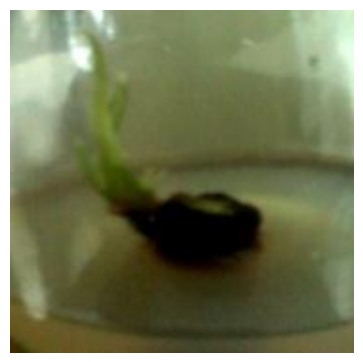

P9

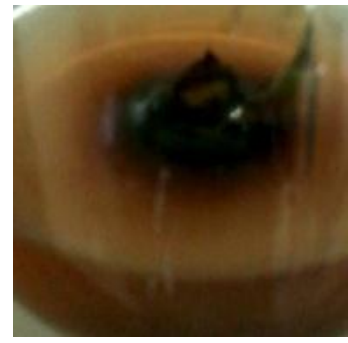

P2

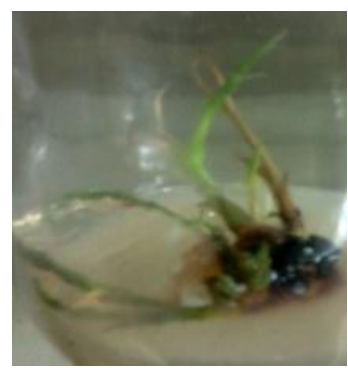

P6

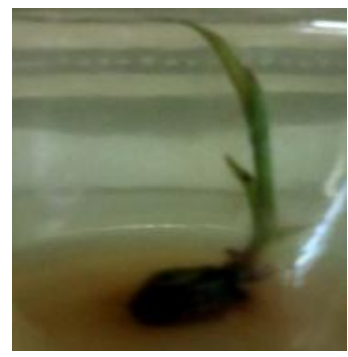

P10

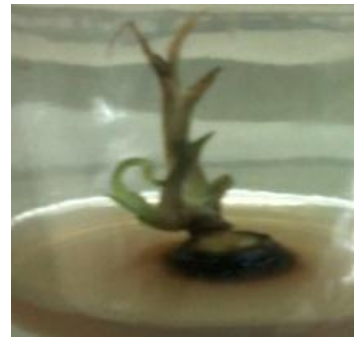

P3

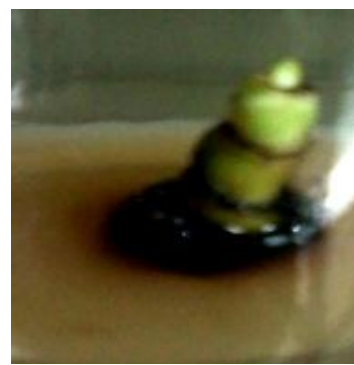

P7

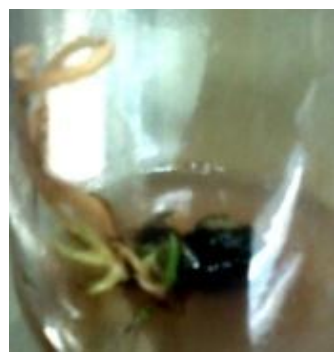

P11

Gambar 1. Tunas tebu var Bululawang pada perlakuan kombinasi ZPT dengan dosis berbeda

Keterangan: P0: Tanpa zat pengatur tumbuh; P1: 0,5 mg/l kinetin; P2: $1 \mathrm{mg} / \mathrm{l} \mathrm{kinetin} ; \mathrm{P} 3: 0,5 \mathrm{mg} / 1 \mathrm{BAP} ; \mathrm{P} 4: 1 \mathrm{mg} / \mathrm{l}$ BAP; P5: $2 \mathrm{mg} / \mathrm{l} \mathrm{BAP;} \mathrm{P6:} \mathrm{0,5} \mathrm{mg/l} \mathrm{BAP} \mathrm{+} \mathrm{0,5} \mathrm{mg/l} \mathrm{kinetin;} \mathrm{P7:} \mathrm{0,5} \mathrm{mg/l} \mathrm{BAP} \mathrm{+} 1 \mathrm{mg} / \mathrm{l} \mathrm{kinetin;} \mathrm{P8:} 1 \mathrm{mg} / \mathrm{l}$ BAP + 0,5 mg/l kinetin; P9: $1 \mathrm{mg} / \mathrm{l} \mathrm{BAP} \mathrm{+} 1 \mathrm{mg} / \mathrm{l} \mathrm{kinetin;} \mathrm{P10:} 2 \mathrm{mg} / \mathrm{l} \mathrm{BAP} \mathrm{+} \mathrm{0,5} \mathrm{mg/l} \mathrm{kinetin;} \mathrm{P11:} 2 \mathrm{mg} / \mathrm{l}$ $\mathrm{BAP}+1 \mathrm{mg} / \mathrm{l} \mathrm{kinetin}$

Perlakuan P11 pada pemberian $2 \mathrm{mg} / \mathrm{l}$ BAP dan $1 \mathrm{mg} / \mathrm{l}$ kinetin menghasilkan tunas dan daun berwarna kuning. Menurut Balazc et al.(1967) penguningan daun terjadi karena adanya nekrosis (kerusakan sel), dan menurut Kocot et al. (2011) nekrosis terjadi karena gejala defisiensi $\mathrm{Mg}^{2+}$. Menurut Pallavi dkk. (2012) kerusakan sel akan memicu terjadinya browning atau pencoklatan pada eksplan karena adanya hidroksilasi senyawa flavonoid tebu seperti: apigenin dan luteoledin oleh enzim polifenol oksidase (PPO) menghasilkan kuinon yang akan menyebabkan eksplan berwarna cokelat (Blackweel, 2012).

Perlakuan P1 dan P2 terlihat tunas yang terbentuk kecil, karena pada pemberian kinetin dengan konsentrasi $0,5 \mathrm{mg} / \mathrm{l}$ dan $1 \mathrm{mg} / \mathrm{l}$ kemungkinan konsentrasi kinetin yang tinggi akan menghambat akumulasi ion $\mathrm{Ca}^{2+}$ yang berperan dalm menurunkan osmotik sel. Menurut Schumaker dan Gizinski (1993) kinetin berperan dalam menstimulasi pemasukan $\mathrm{Ca}^{2+}$ melalui saluran membran plasma. 
Tabel 2. Warna tunas lateral tebu var. Bululawang usia 3 MST

\begin{tabular}{ccc}
\hline Perlakuan & $\begin{array}{c}\text { Tunas } \\
\text { lateral }\end{array}$ & Warna tunas \\
\hline P0 & Ada & Hijau tua \\
P1 & Ada & Hijau tua \\
P2 & Ada & Hijau tua \\
P3 & Ada & Hijau tua \\
P4 & Ada & Hijau muda \\
P5 & Ada & Hijau muda \\
P6 & Ada & Hijau \\
P7 & Ada & Hijau muda \\
P8 & Ada & Hijau tua \\
P9 & Ada & Hijau muda \\
P10 & Ada & Hijau tua \\
P11 & Ada & Kecoklatan \\
\hline
\end{tabular}

Keterangan: P0: Tanpa zat pengatur tumbuh; P1: 0,5 mg/l kinetin; P2: $1 \mathrm{mg} / \mathrm{l} \mathrm{kinetin;} \mathrm{P3:} \mathrm{0,5} \mathrm{mg/l} \mathrm{BAP;} \mathrm{P4:} 1 \mathrm{mg} / \mathrm{l}$ BAP; P5: $2 \mathrm{mg} / \mathrm{l} \mathrm{BAP}$; P6: 0,5 mg/l BAP + 0,5 mg/l kinetin; P7: 0,5 mg/l BAP + $1 \mathrm{mg} / \mathrm{l} \mathrm{kinetin;} \mathrm{P8:} 1 \mathrm{mg} / \mathrm{l}$ BAP + 0,5 mg/l kinetin; P9: $1 \mathrm{mg} / \mathrm{l} \mathrm{BAP} \mathrm{+} 1 \mathrm{mg} / \mathrm{l} \mathrm{kinetin;} \mathrm{P10:} 2 \mathrm{mg} / \mathrm{l} \mathrm{BAP} \mathrm{+} \mathrm{0,5} \mathrm{mg/l} \mathrm{kinetin;} \mathrm{P11:} 2$ mg/l $\mathrm{BAP}+1 \mathrm{mg} / \mathrm{l} \mathrm{kinetin}$

\section{KESIMPULAN}

Pemberian BAP dan kinetin pada konsentrasi $0 \mathrm{mg} / \mathrm{l}$ sampai $1,5 \mathrm{mg} / \mathrm{l}$ dan $2 \mathrm{mg} / \mathrm{l}$ tidak berpengaruh terhadap waktu munculnya tunas tebu var. Bululawang, namun pada pemberian BAP $1 \mathrm{mg} / \mathrm{l}$ dan kinetin $1 \mathrm{mg} / \mathrm{l}$ induksi tunas cenderung cepat. Pemberian BAP dan kinetin pada konsentrasi $0 \mathrm{mg} / \mathrm{l}$ sampai $1,5 \mathrm{mg} / \mathrm{l}$ dan $2 \mathrm{mg} / \mathrm{l}$ tidak berpengaruh terhadap pertumbuhan tunas tebu var. Bululawang, namun pada konsentrasi BAP 0,5 mg/l panjang tunas cenderung tinggi sedangkan pada konsentrasi BAP $0,5 \mathrm{mg} / \mathrm{l}$ dan kinetin $0,5 \mathrm{mg} / \mathrm{l}$ jumlah tunas dan jumlah daun cenderung lebih banyak.

\section{DAFTAR PUSTAKA}

Ai, N.S., dan Yunia, B. 2011. Konsentrasi Klorofil Daun sebagai Indikator Kekurangan Air pada Tanaman. Jurnal Ilmiah Sains. 11(2).

Ali S., Hasan S.W., Razl, Shah S., and Amir R. 2004. Micropropagation of Sugarcane Through Bud Culture. Sarhad Journal Agriculture. 20: 79-82.

Blackweel, W. 2012. Food Biochemistry and Food Processing. New York: Academic Press.
Balazc, E., Barna, B., and Kiraly, Z. 1967. Effect of Kinetin on Lesion Development and Infection Sites in Xanti-nc Tobacco Infected by TMV. Acad Science. 11: 1-9.

Chen, J., Henny, R.J. and Connell, M.C. 2002. Development of New Foliage Plant Cultivar. Florida Agriculture. 117-121.

Ruzic, D., Tatjana, V., Slobodan, M., Radosav, C. and Rade, M. 2008. The Influence of Imidiazole Fungicide on Multiplication In vitro of Pyradwarf Pear Rootstock. Austarlian Journal of Crop Science. I(2): 63-68.

Gaudino, R.J. and Pikkard, C.S. 1997. Cytokinin Induction of RNA Polymerase Transcription in Arabidopsis thaliana. Journal Biology Chemistry. 272: 6799-6804.

George, E. F., Michael, A.H., and Geert-Jan, D.K. 2008. Plant Propagation By Tissue Culture $3^{\text {rd }}$ Edition. Springer: The Netherlands.

Harjadi, S.S. 2009. Zat Pengatur Tumbuh. Swadaya: Jakarta.

Hayati, S.K., Y. Nurchayati, dan N. Setiari. Induksi Kalus dari Hipokotil Alfalfa (Medicago Sativa L.) secara In Vitro dengan Penambahan Benzyl Amino Purine (BAP) 
dan A-Naphtalene Acetic Acid (NAA). Bioma 1(12): Hal. 6-12.

Khairina, R. 2001. Pengaruh Konsentrasi Benzil Aminopurin terhadap Pertumbuhan Eksplan Tanaman Jeruk manis (Citrus sinensis L.) secara Kultur Jaringan. RKIP: Pekanbaru.

Kocot, K.P., Andrzej, K, and Aleksandra, H. 2011. The Effect of Kinetin On The Chlorophyll Pigments Content in Leaves of Zea mays L. Seedlings and Accumulation of Some Metal Ions. University of Silesia 397-409.

Murwandono. 2013. Budidaya Tebu di Indonesia. Balittas: Malang.

Malabadi, R.B., G.S.Mulgund, K.Macuoja, and S.V.Kumar. 2011. Induction Of Somatic Embryogenesis In Different Varieties Of Sugarcane (Saccharum officinarum). Plant Biology. 1(4) : 39-48.

Niaz and Quraishi. 2002. Effect of Growth Regulators on The Regeneration Potential of Two Sugarcane Cultivar SPF 213 and CPF 237. Biology Science. 5(10): 1081-1083.

Pallavi, R., Elakkiya, S., Sai, S.R.T., and Suganaya, D. 2012. Anthocyanin Analysis and Its Anticancer Property from Sugarcane (Saccharum officinarum L.). Journal of Research Pharmacy and Chemistry India.

P3GI. 2008. Teknologi Bud Chip. Puslitbang: Kediri.

Pierick, R.L.M. 1982. In vitro Culture of Higher Plant. Departement of Horticulture: England.

Schmulling T. 2004. Cytokinin. Elsevier Science: University of Berlin.

Schumaker, K.S., and Gizinski, M.J. 1993. Cytokinin Stimulates Dihydropyridine Sensitive Calcium Uptake in Moss Protoplasts. Academy Science. 90: 1093710941.

Sukmadajaja Deden. 2011. Regenerasi dan Pertumbuhan Beberapa Varietas Tebu (Saccharum officinarum L.) secara In Vitro. Jurnal AgroBiogen7.
Vujovic T., D.J. Ruzic and R. Cerovic. 2012. In vitro Shoot Multiplication as Influenced By Repeated Subculturing of Shoot Contemporary Fruit Rootsocks. Horticulture Science. 3: 101-107.

Warewing P.F. and I.D.J.Phillips. 1981. Growth and Differentiation in plants. Pergamon: New York.

Yusnita. 2003. Kultur Jaringan Cara Memperbanyak Tanaman secara Efisien. Agromedia: Jakarta. 